\title{
Negritude Rediscovered: A Reading of Andre Brink's States of Emergency
}

\author{
Sucheta Sarjerao Patil. ${ }^{1}$ Dr. Pradnya V. Ghorpade. ${ }^{2}$ \\ ${ }^{1}$ Research Student, Department of English, Shivaji University, Kolhapur (MS), India. \\ ${ }^{2}$ Associate Professor, Dept. of English, K. R. P. Kanya Mahavidyalaya, Islampur, (MS), India.
}

\begin{abstract}
Negritude is a literary and ideological movement lead by francophone black intellectuals, writers and politicians. The doctrine of Negritude is the intellectual paraphrasing of the whole range of reactions of the world of black people against foreign oppression, against foreigner's dehumanising infliction of colourcomplex. It basically projects the essential human values of man, transcending all superficial barriers that divide human beings. Although there are acute national differences among the African nations, the spirit of Negritude cuts across the whole body of African literature. Andre Brink is acknowledged as one of the prominent novelists in South Africa. Through his work, he has prompted an awareness of the problems of his society, explored their roots and expressed opposition to repressive authorities. The present paper attempts to present Negritude as reflected in Andre Brink's novel,States of Emergency. In the novel, Brink attempts to subvert the repressive and oppressive apartheid system. It is a serious appeal to humanity for a reflection upon the marginalization of black as a racially discriminated class of second-rate citizens. As a white South African writer, the contribution of Brink to the liberation of the Blacks is remarkable.
\end{abstract}

Key words: Negritude, race relations, Andre Brink, apartheid, discrimination, marginalization.

Negritude is a literary and ideological movement lead by francophone black intellectuals, writers, and politicians. It is not merely a word coined by any political enthusiast but the dream of a whole people, which crystallised in the mind of that great poet Aime Cesaire.As Pradnya Ghorpade rightly points out, "the fundamental objective of the movement and its founders was to define black aesthetics and black consciousness against a background of racial injustice and discrimination around the world" [1]. Cesaire coined the term 'negritude' to describe the politicized cultural identity of these people. And this identity of the African has been a source of ridicule from the West; at one point everything dark was inferior and devilish.It was in response to this background that Senghor developed a colour based identity for the African. According to him: "Negritude is the whole complex of civilised values cultural, economic, social and political which characterize the black peoples, or more precisely, the Negro-Africa world" [2]. Pramod Nayar observes:

Leopold Senghor turned negritude into a major political project and programme. He used negritude alongside socialism and preached a Pan-African identity, arguing that Africa had achieved socialism well before the Europeans... Senghor has proposed a Pan-African identity where African states would be in a horizontal relationship with each other but would also have an affiliation with Europe [3].

Senghor modified Negritude's basic tenets in seeking a new humanism based on the cross-fertilization of European and African values. Overall, the doctrine of Negritude is the intellectual paraphrasing of the whole range of reactions of the world of black people against foreign oppression, against foreigner's dehumanising infliction of colour-complex. It is also the result of the historic process of self-identification of the great people. The doctrine basically projects the essential human values of man, transcending all superficial barriers that divide human beings. Negritude, therefore, emphasises the oneness of mankind. It is a reaction to colonialism which provides Africans with new ideas, new cosmologies and new ideologies.

Although there are acute national differences among the African nations, the spirit of 'negritude' cuts across the whole body of African literature. South Africa's unique social and political history has generated a rich variety of literatures, with themes spanning pre-colonial life, the days of apartheid, and the lives of people in the "new South Africa". Mali and Ghorpade observe, "South African people had to live under the laws imposed by colonialist and had to face the crisis of values generated by the colonial politics. South African writers depict the crisis and contradictions faced by the people" [4].The conflict between the people of the land and the rulers from the European continent left scars in the minds of the natives, which were recorded by the victimised writers of South Africa. Many of the first black South African authors were missionary-educated, and many thus wrote in either English or Afrikaans. One of the first well known novels written by a black author in an African language was Solomon Thekiso Plaatje's Mhudi (1930). Notable white South African authors who wrote in English include Nadine Gordimer, J. M. Coetzee, Andre Brink etc.Andre Brink is acknowledged as one of the prominent 
novelists in South Africa and one of the most dogged Afrikaner critics of the apartheid system. He wrote both in Afrikaans and English languages.He struggles to fulfil his assumed role of artist. He remains compromisingly committed to the struggle against the apartheid system. As a white South African writer, the contribution of Brink to the liberation of the Blacks is noteworthy.

The present paper proposes to investigate reflection of Negritude in Andre Brink's novel,States of Emergency. During the height of the 1984-86 township turmoil, Brink finds him unable to write for more than two years. He breaks his unhappy silence with States of Emergency, a complex novel. The novel shows an outstanding novelistic deftness. The story consists of notes towards a love story, "clearly situated in contemporary South Africa, in the period of intense political unrest marked by the 'States of Emergency' declared by the South African government in 1985" [5]. The story skilfully interweaves public and political emergency of conducting an illicit love affair in the midst of ceaseless violence and upheaval. The nameless narrator is a South African writer, who struggles to perfect a love story untarnished by politics. But the political fact of apartheid intrudes constantly on the story-within-a-story romance of Philip Malan and Melissa. Philip, a married, fiftyish man who is a South African professor and Melissa is his 23-year-old graduate student. But sexual and domestic chaos is only complemented, even overshadowed, by what goes on in the country: the ever-tightening noose of the Emergency, with police run amok on the campuses and become pure murderous outlaws in the townships. Lucas Wilson is Melissa's ex-boyfriend, an up-coming instructor. He leads anti-apartheid protest that shakes her complacency. And Philip breaks off an affair with a woman from Martinique during the Paris riots of 1968 because of their ethnic differences-a move; he now considers a repugnant act of cowardice. A second plot is introduced when the narrator discovers the feverish diary of a white woman, Jane Ferguson. She is recently burned to death. She has been romantically involved with Chris de Villiers, a political escapee on run from the Security Police. These separate love stories collide and interpenetrate in the narrator's imagination, against a backdrop of escalating racial violence. Brink demonstrates that neither love nor art offers an escape; even the imagination is determined by political realities.

The novel profoundly projects Negritude as a reaction to colonialism.Ntombzana is the child of Melissa's landlord's char, Rosie. She gets killed by a police constable with his pistol. He considers her death as "a joke"[6]. Melissa helps Rosie to face the reality. She goes with her to the police office, to the hospital, the morgue, and after identifying the body, she takes Rosie to a lawyer, then back to the police. This incident changes Rosie's humanistic view. Earlier she is a motherly person in the world, who wants her sons to become teachers or doctors. But after her daughter's murder "there is only one thing she's going to bring them up for now ...to kill policemen" [7].The story of Jane Ferguson and Dr. Chris de Villiers focuses the antiracist activities more profoundly than their love relation. Jane is a white girl, who arrives at her uncle's, Jock's hotel to help him in arrangement of the hotel. There she falls in love with a strange visitor of their hotel, Clive de Vos, who is actually Dr. Chris de Villiers. She comes to know about it only after her full involvement in him. The truth causes a great upheaval in her mind. She realises that Chris is a political escapee on the run from Security Police. Throughout the text, there are extracts from Jane's manuscript which appear, in recognizably similar yet slightly different form, "as the writer's own narrative construct" [8]. In this connection Kossew comments: "Embedded within the text, too, is Jane's own diary, brought to the writer by her father, which contains the 'real-life' love story upon which she has based her novella and which identifies the young man she fails in love with as Chris" [9].

The notations from Jane's diary contain some important features of Negritude. On the occasion of theirfirst visit, Jane and Chris have their tea together and take a long walk. In the evening, as usual guinea-fowls begin to make noise. Jane used to watch them as usual. But she is interrupted by Chris. She tells him about the difficulties created by Uncle Jock to the guinea-fowls andabout his endless efforts to scare them off. Chris is irritated withJock's activities and calls him selfish. He argues: "They [guinea-fowls] were here first, weren't they? Surely he's [Uncle Jock] the one who must learn to live with them, not the other way round" [10]. Here, guineafowls symbolically representNegro Africans, who are the natives of Africa and Uncle Jock represents the colonizers, the white races, who come to African land much later. But,they claim ownership of the land by abolishing the black natives, who have to struggle for their rights in their own homeland.As time passes, Chris begins to trust Jane and tells her about his spontaneous past. He is a medical doctor and tries to rescue a young son of a trade union leader from police. The boy dies in the custody and Chris becomes an eyewitness of his humiliation. This humiliation irritates him and he lays a complaint against police. But, he finds that it is impossible to pin down police. From then onwardshe gets more involved with the black unions and campaigns against the government. He loses the case against police and consequently loses his job too. But from that moment his whole life changes drastically. "Black people just turned up on my doorstep. All kinds of personal problems. Some came specially to tell me they wanted to be friends with me. A whole new world opened up to receive me" [11]. And finally, dealing with the case of that black boy, he has to run into exile, to run from Security Police. Negritude movement seeks remedy on identity crisis through acceptance of blackness. It asks to feel pride in being black. It seeks remedy through valorisation of African history, traditions and beliefs. In the novel,the police take away Lucas Wilson along with twenty or thirty other students, men and women on the 
occasion of his demonstration at the University.Philip's opinion about students' revolt is changed. Though he decides to join "tomorrow's march" [12] along with Melissa, he knows that there is no use of a speech and of all those slogans, but "one has got to do something" [13]. So, he drives to the police station and pays bail for Lucasand takes him home. During the march, they break into song "Nkosi Siklel iAfrika" [14]. According to Philip, this is "the saddest and most beautiful anthem in the world" [15]. While listening the anthem Philip goes through the experience of oneness of humanity: "There is no ' $\mathrm{I}$ ' or 'you' left; they are no longer a thousand individuals standing there: in the simplicity of this singing all separateness is transcended" [16]. In this regard KennethClark points out:

The great tragedy- but possibly the great salvation, too - of the Negro and white in America is that neither one can be free of the other. Each Negro is a little bit white, and every white is little bit Negro, in the sense that neither is totally alien from the other. Both are caught in a common human predicament. Each needs the other, the white to be free of his guilt, the Negro to be free of his fear... [17].

In another incident, Chris tells Jane about his experiences at black townships which clearly carry the theme 'black is beautiful': “... on this side of the wall people haven't a faintest idea of what goes on 'over there'. But it's exhausting... Every waking moment you are exposed to suffering: just the endless pain that goes with being black in a place like this. And there's so little one can do" [18].He doesn't want to exchange his friendship with blacks and the moments he has spent with them "for anything" [19]. He praises black for their virtues. According to him, black is beautiful. He says, "A [black] guy may have only a crust of bread in his house but he'll share it with you. If you need a place to sleep, someone will offer you his bed and sleep on the floor himself" [20]. Further he argues that, "There's a togetherness, a kind of infectious faith in the future which goes beyond anything I've ever known on the 'white' side" [21].

Jane's diary tells us about Chris's arrest by the SB in Johannesburg under Article 29 of the Internal Security Act which can mean "anything"[22]. She comes to know about his death from radio announcement, which declares "the notorious ANC activist committed suicide in his cell at John Vorster Square" [23]. But Jane believes that Chris would never commit suicide. It proves true, when she receives his letter written on a toilet paper, from John Vorster Square, Johannesburg. The letter comes with a detainee who is released a week ago. It carries a message of equality:“...I've never believed in wasting my time with futile and (illegible) feeling of guilt. Yet in a very profound sense I feel I'm purging my own whiteness"[24]. His relations with black remain unchanged during imprisonment. He continues:

I'm no longer allowed to be exceptional; I am not spared anything because I'm white. Their trust has not been misplaced... The colour of our skins no longer separates us... We whites so often tend to think of the 'catastrophe' ahead, the great 'explosion', the 'apocalypse'. But it's really only a blind wall caving in to reveal a landscape which is (illegible) no, not 'beautiful' in any utopian sense, but worthwhile. Yes, that's it. Worthwhile. Worth everything[25].

In this connection, A. J. Hassall remarks: "In Brink's South Africa, Blacks and Whites are seen as natural equals separated only by the uncompromising racism of the Whites" [26].

Negritudeassumes that emotions play a dominating role in the entire Negro-African cultural system. Brink strongly opposes the cultural isolation of Negros. He glorifies Negro-African culture through glorification of Milton's family history. Milton Thaya is a black teacher, who eventually visits the narrator. He gets a role in his literary work as well. His frequent visits are changed into rare ones after the declaration of states of emergency. He takes risk in visiting the narrator during one night to get money to buy a coffin for his landlord Mister Mtuze. He gets success in negotiations and gets help from the narrator as well as from his protagonist, Philip. Though, both the narrator and the protagonist of his novel are white, both are aware of malicious effects of racism. They want to treat black on equal terms. He creates a picture of paradise in Philip's mind in his childhood, which proves the one of hell in his youth. In his childhood "everything was preordained, every person knew his proper place. On the farm: the white were the masters, the blacks their trusty servants. It had reassurance of biblical sanction" [27]. But, when he leaves home for further education, he reaches Europe and there he realizes: "What he'd taken for paradise was, in fact, hell. It had seemed like paradise only because he was white, and privileged. Now all the customs and habits and traditions and structures which had bolstered his life turned out to be evil, the very opposite of what he'd always taken them to be" [28]. It is his visit to Europe that brings drastic shift in his intellectual and emotional perspective: "It was as if, in one stroke, the validity of all his memories was cancelled. He had nothing left but shame" [29]. It seems that Brink is infected with the "new awareness among white Afrikaners of the common humanity of all people regardless of color" [30].

Both the black and white characters in the novel give importance to their families. Family is seen as a centre of the social structure inNegritude. We see Milton taking risk in visiting the narrator during one night to get money to buy a coffin for his landlord, Mister Mtuze. Mtuze is 'necklaced' by the comrades, who suspect him as an informer of the "amangundwane" [31]. But, when the narrator wants Milton to stay out of the mess, he explains him that he takes the risk for safety of his children and of township. He explains: "But if he [Mtuze] doesn't get buried the whole township will go up in the flames. And it's my children I'm worrying about" [32]. The narrator 
gets convinced with his foresight and lends him money. He asks him to stay his house for rest of the night and not to take risk in the streets in a curfew. But, Milton rejects his idea reminding him that "the township people don't like us mixing with whites" [33]. When the narrator tries to convince him by telling that they are friends. Milton's reply is quite significant in emergency terms:"You don't know those young comrades. It's just black and white to them. And whitey can't be anybody's friend" [34]. The narrator tries to sort out his thoughts of a love story untarnished by politics.Besides, Milton struggles for Mister Mtuze's funeral to be done without interruption as early as possible in reality. In the other example, Milton visits Melissa on the background of school boycotts, to get help to build an alternative education system for the black. Melissa is unable to help with money. But she agrees to take "a class of first-graders" [35], and to solve the money problem she takes him to Philip. But when Philip hesitates to help on the ground of their safety, Milton suddenly admits that he doesn't "want to endanger other people's lives" [36]. Finally, he gets a big financial help from Philip. He gives a goldcoin, 'a real Kruger pound' [37], dated back- 1898 to Philip. The coin belongs to his grandmother. It is not just a coin for him, but his whole history is associated with it. So it is very valuable for him. He tells Philip "There you got my whole history in your one hand" [38]. We come to know about his grandmother's struggle to carry her illegal child, conceived from her white master. She suffers a lot, even goes through "a thrashing of a sjjambok" [39], and walks almost two hundred miles to reach Port Elizabeth.She gives birth to her child and successfully raises her family, "no matter how bad things got for her" [40]. On the contrary, Melissa is worried about her unborn children. She thinks it horrible to bring up children in such repressive conditions. Thus, both black and white characters worry for their children and families. This implies Brink's concern with family as a centre structure of society and its culture.

Brink, through the writing of his unnamed narrator, the author-figure, describes history of South Africa. He gives references to various violent situations through which the nation has to go during apartheid. Senghor believed that the federal system of government is the only kind of democracy that would help Africa. So he developed political Negritude in an active humanism. In the novel,Brink reports his dislike of unequal treatment given to black at every step of life. For instance, he compares two different incidents "revealing the different ways in which the press reported these two incidents" [41]. One event is of Uitenhage outrage, in which the victims are black. This incident has occurred far away, "beyond the periphery of white suburbs and consciousness [42]. Though it gets massive press coverage, "these reports discussed the massacre within the context of politics" [43]. The narrator describes the notion of press coverage, which gives "no 'human interest' here... No biographies, interviews, commentaries to establish what had happened belonged not only to the political statistics of the country but concerned ordinary men, women, children" [44]. On the contrary, the accident of a school bus, which drives into a lake, in Westden, leaving forty-two children dead, has received massive coverage of both English and Afrikaans newspapers. This happens, because, as the narrator ironically points out: "the children were white, cut off tragically in the prime of their youth"[45]. Brink's rage on apartheid becomes clear, when his narrator describes these children as: "the elected of Lord Jesus, the purest pearls of His eternal crown" [46]. His views on racism maintain a sharp edge of satire, when the narrator further argues:

Think of it: all those beautiful white children would have married in due course, to produce children of their own. One can calculate for oneself what a loss was sustained by the White race of Southern Africa, established here by the will of God Almighty. The others had sprouted from the soil by themselves, like weeds in a well-panned mealie land [47].

In another incident, the narrator thinks of various possibilities of encounter between Philip and Lucas (Melissa's ex-boyfriend). He creates chances for various reactions to states of emergency. Lucas tries to convince Philip to support a protest march, which is to be organised against the COSAS ban by the students. But Philip wants the university, as an institution, to stay out of it. For him "the university is a centre of learning. No strings attached" [48], though he agrees that "students should protest, because the ban affects them all" [49]. Thus, Brink finds himself dedicated to the ideal of changing apartheid.

Realistic writing is an important aspect of Negritude. A critic remarks in The Age that, "all of the incidents described in the novel are either real or based on real-life events" [50]. The narrator inserts historical elements to flourish a love story between Philip and Melissa on the backdrop of political turmoil. The review quotes some examples from real-life, which are described in the novel, such as: "The point blank shooting of the girl by a policeman who later claimed it was a prank, for example, took place in Brink's home region of the Eastern Cape; murders in which a petrol filled tyre "necklace" left victims looking like charred tree trunks were a horrifying fact of life at the time" [51].Brink deliberately inserts historical and political elements in the novel to make it more realistic. He deals with racial inequality in the South African scenario. He makes his white characters supportive to the revolts of Black for equality. Melissa describes her experience of the march and agrees, "for the first time I think I really understood what the black people in the townships are feeling" [52]. Besides, when Jane acquires real knowledge of black world from Chris, she regrets her own life. She feels "guilty about everything I've always liked about my own life" [53]. But, Chris blames the whole white race for their (blacks') humiliation "It's not you, Jane, it's all of us. Damned to privilege, sentenced to comfort, imprisoned in our whiteness. Not caring, or even knowing, about what's happening to 'them"' [54]. He regrets:

DOI: 10.9790/0837-2108011116 www.iosrjournals.org $\quad 14 \mid$ Page


How did we ever get into this mess of "us" and "them"? For God's sake, we're all in it together we're all "us". It's like being deprived of one's own shadow: we of them, they of us. You know what really happens when one loses one's shadow? - it means the sun has set, the light has gone out. We're all groping in the dark. Will we ever find each other again [55].

Here, Brink gives a call for a changed social consciousness. This call, according to Leo Kuper, is:

A characteristic of revolutionary social movements, and perhaps of all social movements whether directed against class exploitation, cultural repression, caste exclusion or racial domination. It is, of course, quite central to the theory of class struggle, in which the working class is exhorted to reject the false consciousness induced by the indoctrination of ruling class definitions, and to acquire a true consciousness of its class situation and revolutionary role [56].

The engagement of white authors like Andre Brink, in discourses of Negritude is not merely an example of Whites contributing to Negros' equal treatment by pointing out an accusing finger at the sources of oppression. It is a question of Whites realising the inequality of their own position in the society.In the novel, Brink advocates for equal rights of all the races, especially of blacks, to bringsocio-economic, socio-political and socio-cultural developments in South Africa. He presents Negro characters as noble, more sensitive, more given to the warmth of life. In the confrontation between white and black, Brink seems to take side of the black, as he believes that the black are unjustly treated by the white. The explicit concern with Negros' predicament and the recognition of the privileges that whites enjoy in the society, make this novel a significant example of a significant movement towards new centres of consciousness. Thus, the novel is an outstanding attempt of literary creation that consciously or unconsciously follows the paved path of Negritude.

\section{REFERENCES}

[1] Ghorpade, Pradnya. Nadine Gordimer: A Writer with A Difference (Kanpur: Vidya Prakashan, 2012$) 76$.

[2] Senghor, L. S. "Negritude: A Humanism of the Twentieth Century." Ed. P. Williams and L. Chrisman. Colonial Discourse and Post-colonial Theory (London: Longman, 1993: 27-35) 33.

[3] Nayar, Pramod. Postcolonial Literature: An Introduction (New Delhi: Pearson, 2008) 89.

[4] Mali, Ujwala and Pradnya Ghorpade. "Political Protest in Alan Paton's Ah, But Your Land is Beautiful". The Criterion: An International Journal in English (Vol 4, No 5, Sept. 2013: 1-4). Web. (4 May 2016) 1.

[5] Kossew, Sue. Pen and Power: A Post-Colonial Reading of J. M. Coetzee and Andre Brink (Amsterdam Atlanta: Rodopi, 1996) 180.

[6] Brink, Andre. States of Emergency (London: Faber and Faber, 1988) 210.

[7] Ibid. 211.

[8] Kossew 184.

[9] Kossew 184.

[10] Brink 81.

[11] Ibid. 129.

[12] Ibid. 180.

[13] Ibid. 180.

[14] Ibid. 182.

[15] Ibid. 182.

[16] Ibid. 186.

[17] Clark, Kenneth B. "Black and White: The Ghetto Inside." Eds. Frederick R. Lapides and David Burrows. Racism- A Case Book. (New York: Crowell, 1971: 104-120) 105.

[18] Brink 129.

[19] Ibid. 129.

[20] Ibid. 129.

[21] Ibid.129.

[22] Ibid. 178.

[23] Ibid. 193.

[24] Ibid. 202.

[25] Ibid. 202.

[26] Hassall, A. J. “The Making of a Colonial Myth: The Mrs Fraser Story in Patrick White's A Fringe of Leaves and Andre Brink's An Instant in the Wind" (ARIEL: AReview of International English Literature, Vol 18, No 3, July 1987: 3-28) 21.

[27] Brink 64.

[28] Ibid. 64.

[29] Ibid. 64. 
[30] “Andre Brink." Gale Contextual Encyclopaedia of World Literature. Eds. Anne Marie Hacht and Dwayne D. Hayes. All 4 Vol.s. (Farmington Hills: Cengage Learning, 2009: 209-213). Web. 31 Jan. 2016.

[31] Brink 10.

[32] Ibid. 11.

[33] Ibid. 12.

[34] Ibid. 12.

[35] Ibid. 72.

[36] Ibid. 73.

[37] Ibid. 74.

[38] Ibid. 74.

[39] Ibid. 74.

[40] Ibid. 74.

[41] Ibid. 24.

[42] Ibid. 24

[43] Ibid. 24.

[44] Ibid. 24.

[45] Ibid. 24.

[46] Ibid. 24.

[47] Ibid. 25.

[48] Ibid. 175.

[49] Ibid. 176.

[50] “Review: Andre Brink's States of Emergency." (AGENDA, The Sunday Age. The Age.10 Sept. 1989). Web. (19 Dec. 2015).

[51] Review

[52] Brink. 185.

[53] Ibid. 129.

[54] Ibid. 129

[55] Ibid. 129, 130.

[56] Kuper, Leo. Race, Class and Power: Ideology and Revolutionary Change in Plural Societies (London: Gerald Duckworth and Company, 1974) 85, 86. 